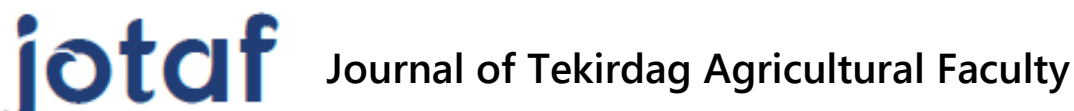 \\ Tekirdağ Ziraat Fakültesi Dergisi
}

Mayıs/May 2020, 17(2)

Başvuru/Received: 01/02/19

Kabul/Accepted: 25/12/19

DOI: $10.33462 /$ jotaf.520836

http://dergipark.gov.tr/jotaf

http://jotaf.nku.edu.tr/

ARAŞTIRMA MAKALESI

RESEARCH ARTICLE

\section{Kaplanmış Yonca (Medicago sativa L.) Tohumlarının Kuraklık Stresi Koşullarında Çimlenme Özelliklerinin Belirlenmesi}

\section{Determination of Germination Characteristics of Covered Alfalfa (Medicago sativa L.) Seeds in Drought Stress Conditions}

\section{Teslime BIÇAKÇI ${ }^{1}$, Elçin AKSU ${ }^{1}$, Mehmet ARSLAN ${ }^{*}$}

\section{$\ddot{O} z$}

Yonca dünyanın ve Türkiye'nin kurak ve yarı kurak bölgelerinde yetiştirilen, otu proteince zengin bir yem bitkisidir. Bu çalışmada, çimlenme ve erken fide gelişimi döneminde çevresel koşullara çok hassas olan yonca tohumlarının çimlenme özelliklerinin geliştirilmesi amaçlanmıştır. Bu amaçla Nimet yonca çeşidinin tohumları Panoramix adlı tohum kaplama preparatı ile kaplanmış ve kuraklık stresi koşullarında çimlendirilmiştir. Denemede Panoramix $2 \mathrm{~L} / 1000 \mathrm{~kg}$ tohum ve $4 \mathrm{~L} / 1000 \mathrm{~kg}$ tohum olmak üzere 2 doz uygulanmıştır. Laboratuvarda yürütülen çalışma, tesadüf parselleri deneme desenine göre 4 tekerrürlü olarak petri kutularında gerçekleştirilmiştir. Her petriye 50 tohum yerleştirilmiş olup; petriler $\% 70$ nem, $20^{\circ} \mathrm{C}$ sıcaklık, 14 saat ışıklı ve 10 saat karanlık olacak şekilde ayarlanmış iklimlendirme kabininde bekletilmiştir. Kuraklık stresi ise $0,-2,-4,-6,-8$ ve -9.8 bar olacak şekilde Polyethylene glycol-6000 (PEG-6000) ile oluşturulmuştur. Sera denemesi, 3 tekerrürlü olarak, \%50 kum + \%50 toprak karışımı ile doldurulan plastik saksılarda ( $1.5 \mathrm{~L}$ ) yürütülmüş ve 4 farklı kuraklık stresi [0 (T0), \%25 (T1), \%50 (T2), \%75 (T3)] uygulanmıştır. Denemenin sonunda, çimlenme oranı, kökçük yaş ve kuru ağırlığı, sapçık yaş ve kuru ağırlığı belirlenmiştir. Sonuçta, tohum kaplama uygulamalarının yonca tohumlarının kuraklık stresi koşullarında çimlenme özelliklerine olumlu katkı yaptı̆̆ belirlenmiştir.

Anahtar kelimeler: Medicago sativa L., tohum kaplama, kuraklık, çimlenme özellikleri

\begin{abstract}
Alfalfa (Medicago sativa L.) is an essential hay product and a protein-rich forage crop which grow in arid and semi arid regions of the world. In this study, to improve the germination properties of alfalfa seeds, which are sensitive to environmental conditions during germination and early seedling development was aimed. For this purpose, seeds of Nimet alfalfa variety were covered with seed coating preparation, named Panoramix and germinated under drought stress conditions. Panoramix was applied in two concentrations; zero (control), 2 liters $1000 \mathrm{~kg}$ of seeds1 and 4 liters $1000 \mathrm{~kg}$ of seeds-1. A laboratory germination experiment was conducted in randomized parcel design with 4 repetitions. Six different drought stress levels $(0,-2,-4,-6,-8$ ve -9.8 bar) were handled in this study and were used Polyethylene glycol-6000 (PEG-6000) to create of drought stress at different levels. Panoramix was applied in 3 doses, as 0 doses (control), 2 liters / $1000 \mathrm{~kg}$ seeds and 4 liters $1000 \mathrm{~kg}$ seeds respectively. 50 seeds was laid in each petri dish and placed in germination cabinet $\left(70 \%\right.$ humidity, $20{ }^{\circ} \mathrm{C}$ temperature 14 hours light (2000 lux) 10 hours darkness). A greenhouse emergence test was performed using plastic pots filled with a mixture $50 \%$ soil $+50 \%$ sand. Four different drought stresses [0 (T0), \%25 (T1), \%50 (T2), \%75 (T3)] were applied to

\footnotetext{
1*Sorumlu Yazar/Corresponding Author: Mehmet ARSLAN, Akdeniz Üniversitesi, Ziraat Fakültesi, Tarla Bitkileri Bölümü, Antalya/TURKEY. E-mail: mehmetarslan@akdeniz.edu.tr (D) OrcID: 0000-0002-2197-4969

${ }^{1}$ Teslime Bıçakçı, Akdeniz Üniversitesi, Ziraat Fakültesi, Tarla Bitkileri Bölümü, Antalya/TURKEY. E-mail: tes_lime@ hotmail.com (iD OrcID: 0000-00015000-6169; ${ }^{1}$ Elçin Aksu, Akdeniz Üniversitesi, Ziraat Fakültesi, Tarla Bitkileri Bölümü, Antalya/TURKEY. E-mail:e.aksu2979@gmail.com (DD OrcID: 00000001-0707-2723

Atıf/Citation: Bıçakçı, T., Aksu, E., Arslan, M. 2020. Kaplanmış yonca (Medicago sativa L.) tohumlarının kuraklık stresi koşullarında çimlenme özelliklerinin belirlenmesi, Tekirdă Ziraat Fakültesi Dergisi, 17(2), 124-136.

CBu çalışma Tekirdağ Namık Kemal Üniversitesi tarafından Creative Commons Lisansı (https://creativecommons.org/licenses/by-nc/4.0/) kapsamında yayınlanmıștır. Tekirdağ 2019
} 
the pots. At the end of the both experiments, germination rate was calculated and the fresh and dry weight of the shoots and roots, length of shoots and roots were determined. The results indicated that the coating treatmens positive contributied to the germination properties of alfalfa seeds under drought stress conditions.

Keywords: Medicago sativa L., seed coating, drought, germination characteristics 


\section{Extendent Summary}

Alfalfa (Medicago sativa $\mathrm{L}$.) is an essential hay product and a protein-rich forage crop which grow in arid and semi-arid regions of the world. The problem of water deficit, extrem. e temperatures and low atmospheric humidity cause drought which limits the maximum yield and performance of the plants. Because, germination, early seedling development and flowering periods are the most sensitive to drought. This study was carried out to improve the germination properties of alfalfa seeds, which are sensitive to environmental conditions during germination and early seedling development. For this purpose, seeds of alfalfa (Nimet) were covered with seed coating preparation, named Panoramix and germinated under drought stress conditions. Panoramix was applied in 2 concentrations; zero (control), $2 \mathrm{~L} / 1000 \mathrm{~kg}$ of seeds and $4 \mathrm{~L} / 1000 \mathrm{~kg}$ of seeds. A laboratory germination experiment was conducted in randomized parcel design with 4 repetitions. Six different drought stress levels $(0,-2,-4,-6,-8$ ve -9.8 bar $)$ were handled in this study and were used Polyethylene glycol6000 (PEG-6000) to create of drought stress at different levels. 50 seeds was laid in each petri dish and placed in germination cabinet $\left(70 \%\right.$ humidity, $20^{\circ} \mathrm{C}$ temperature 14 hours light (2000 lux) 10 hours darkness). A greenhouse emergence test was performed using plastic pots $(1.5 \mathrm{~L})$ filled with a mixture $50 \%$ soil $+50 \%$ sand. Four different drought stresses [0 (T0), \%25 (T1), \%50 (T2), \%75 (T3)] were applied to the pots. At the end of the both experiments, germination rate was calculated and the fresh and dry weight of the shoots and roots, length of shoots and roots were determined. With the increase in the severity of drought stress, the germination, emergence and early seedling growth characteristics of alfalfa seeds were decreased. The results indicated that the coating treatmens positive contributied to the germination properties of alfalfa seeds under drought stress conditions. 
Yonca, değerli yem bitkilerini içine alan geniş bir cins olup 60 kadar türü barındırmaktadır (Rashmi ve ark., 1997). Dünya'da en fazla tarımı yapılan baklagil yem bitkileri içerisinde yer alan yonca, diğer yem bitkilerine nazaran daha yüksek bir yem değerine sahiptir (Yüksel ve ark., 2016). Yoncanın yeşil ve kuru otu vitamin ve protein bakımından zengin olup hayvanlar için lezzetli ve besleyicidir (Demiroğlu ve ark., 2008). Yeşil yem, kuru ot ve silaj olarak değerlendirilebilen yoncadan otlatmak suretiyle de yararlanılmaktadır. Esas olarak büyükbaş hayvan yemi olan yonca, proteince eksik olan yemlerin bu eksikliğini gidermek amaciyla kullanılmaktadır (Avcıoğlu ve ark., 2009). Yonca toprağ1 en ekonomik şekilde değerlendiren yem bitkilerinden olduğu için, biçimlerden yeniden ve kuvvetli şekilde yeni sürgün geliştirme özelliğine sahiptir (Ingram ve Bartles, 1996). Örneğin, Güney ve Güneydoğu bölgelerimizde yonca 1 yılda ortalama 7-8 defa biçilebilmektedir (Açıkgöz, 2001). Bunun yanında buğdaygil yem bitkileri ile iyi bir karışım oluşturduğu için hayvanlar açısından daha yararlı bir kaba yem olmaktadır (Pecetti ve ark., 2008).

Bitkilerin maruz kaldıkları kuraklık, tuzluluk, yüksek veya düşük sıcaklık gibi önemli abiyotik stres faktörleri tarımsal üretimde verim kayıplarına neden olmaktadır (Janmohammadi ve ark., 2008). Bunlardan kuraklık, genel anlamda meteorolojik bir kavram olarak toprağın içerdiği su ile bitkilerin gelişmelerinde önemli oranda azalmaya sebep olabilecek yağış olmadan geçen dönemi ifade etmektedir (Örs ve Ekinci, 2015). Bu yağışsı dönemde kuraklığın oluşması; toprağın su tutma kapasitesi ve bitkiler tarafından gerçekleştirilen evapo-transpirasyon hızı ve miktarına bağlı olarak meydana gelmektedir (Kalefetoğlu ve Ekmekçi, 2005). Kuraklık dünya genelinde tarımsal amaçlı kullanılan alanların yaklaşık \%26'ında etkili olmaktadır. Bu açıdan bakıldığı zaman, kuraklığın en büyük çevresel stres faktörlerinden birisi olduğu söylenebilir (Blum, 1986; Kalefetoğlu ve Ekmekçi, 2005). Su kısıtlılığı sorunu, ekstrem sıcaklıklar ve düşük atmosferik nem ile bitki verimi ve performansını en fazla sınırlandıran kuraklığa neden olmaktadır (Mostafavi, 2011). Bitki türlerine göre değişmekle birlikte, çimlenme, erken fide gelişimi ve çiçeklenme dönemleri kuraklığa en hassas dönemlerdir (Ahmadi ve ark., 2009).

$\mathrm{Bu}$ tarz stres faktörlerine karşı mücadele amacıyla geleneksel ıslah yöntemleri, biyoteknolojik uygulamalar ve moleküler destekli seleksiyon teknolojilerin yardımıyla dayanıklı/toleranslı tür ve çeşitlerin geliştirilmesi en akılcı çözüm olarak görülmektedir (Samancıoğlu ve Yıldırım, 2015). Ancak bu yöntem ve uygulamaların yüksek maliyetli olması ve uzun zaman almasından dolayı daha pratik çözümler üzerinde durulmaktadır. Bugünlerde, stres koşullarında yetiştirilen bitkilere tolerans kazandırmak ve çimlenme ve erken fide gelişme dönemini garantiye almak adına birçok etken madde ile tohumlar kaplanmaktadır (Kaufman, 1991).

Tohum kaplamanın temel amacı tohumun orijinal haline göre daha büyük, yuvarlak, yumuşak, ağır ve uniform bir hale gelmesini sağlamaktır (Valdes ve Bradford, 1987). Kaplanmış tohum birçok ekim makinesi ile istenilen sıra arası mesafe ile derinliğe ekilebilir (Kaufman, 1991). Bunun yanında kaplama yöntemi ile tohumun çimlenme performansını arttıracak veya çimlenme ve fide döneminde hastalık ve zararlılarla mücadele materyallerinin taşınmasına olanak sağlanmaktadır (Taylor ve ark., 1998). Bu amaçla rhizobacteria grubu bakterilerin biokontrol amaçlı tohumlara kaplama yoluyla taşınması uygun tekniklerden birisidir (Deaker ve ark., 2004; Junges ve ark., 2013; Vavrina ve McGovern, 1990).

$\mathrm{Bu}$ çalışmada, tohum kaplama uygulamalarının kuraklık stresi koşullarında çimlendirilen yonca tohumlarının çimlenme, çıkış ve erken fide gelişimi üzerine etkileri araştırılmıştır.

\section{Materyal ve Metod}

\section{Materyal}

Bu araştırma Akdeniz Üniversitesi Ziraat Fakültesi Tarla Bitkileri Bölümünde laboratuvar ve sera koşullarında gerçekleştirilmiştir. Denemede bitkisel materyal Nimet yonca çeşidinin hasat sonrası hiçbir işlem görmemiş tohumları kullanılmıştır. Kaplama materyali olarak ise, yeni nesil bir tohum kaplama preparatı olan ve Trichoderma harzianum, Bacillus subtilis ve Bacillus megaterium içeren Panoramix tercih edilmiştir. Panoramix, Koppert Biological Systems firmasından temin edilmiştir.

\section{Yöntem}

$\mathrm{Bu}$ araştırma; laboratuar koşullarında çimlendirme denemeleri ve sera koşullarında saksı denemeleri şeklinde planlanmıştır. Panoramix tohumlara $2 \mathrm{~L} / 1000 \mathrm{~kg}$ tohum (Kaplama 1) ve $4 \mathrm{~L} / 1000 \mathrm{~kg}$ tohum (Kaplama 
2) olacak şekilde 2 doz uygulanmıştır. Ayrıca 0 doz uygulaması ile de kontrol denemeleri oluşturulmuştur. Tohumlar Panoramix laboratuar ortamında karıştırılarak kaplanmıştır.

Laboratuar Denemesi: tesadüf parselleri deneme deseninde 4 tekerrürlü olarak yürütülmüşstür. Tohumların çimlenme dönemlerinde kuraklık stresine tepkilerini incelemek amacıyla 6 farklı kuraklık seviyesi belirlenmiş̧ir. Bu kuraklık stresi seviyelerini oluşturmak amacıyla PEG-6000 ile 0, $-2,-4,-6,-8$ ve -9.8 bar su tutma gücüne sahip solüsyonlar kullanılmıştır. Her bir kuraklık seviyesine ait ozmotik potansiyeller Michel ve Kaufmann (1973)'nın önerdiği şekilde ayarlanmıştır. Polietilen glikol (PEG), yüksek molekül ağıllıklı bir madde olup su alımını düzenleyerek, ortamda su stresi olușturmaktadır. Bununla birlikte PEG-6000 bitki köklerince alınmamakta ve bitkilere herhangi bir toksik etki oluşturmamaktadır. PEG-6000 ile hazırlanan çözeltinin oksijeninin zamanla azalması nedeniyle çimlendirme ortamının kâğıtları Çarpııı ve Erdel (2015)'in önerdiği şekilde 3-4 günde bir değiştirilmiştir.

Kuraklık testinde toplam 72 adet $15 \mathrm{~cm}$ çapında petri kabı kullanılmıştır. Kaplanmış yonca tohumları, içerisinde çift katlı çimlendirme kâğıtları bulunan petri kaplarına 50 adet olacak şekilde yerleştirilmiştir. Çift katlı çimlendirme kâğıtları arasında yerleştirilen tohumların üzerine $10 \mathrm{ml}$ farklı PEG6000 yoğunluklarını içeren solüsyonlar dökülerek ve ardından buharlaşmayı engellemek için petri kaplarının etrafı parafilm ile sarılmıştır. Bu işlemlerden sonra petriler 10 saat karanlık, 14 saat aydınlık koşullara sahip, $20 \pm 1{ }^{\circ} \mathrm{C}$ sıcaklığa ayarlanmış çimlendirme kabinlerine konulmuştur. Petriler burada 10 gün boyunca tutulmuş ve sonrası açılan petrilerde gerekli gözlemler alınmıştır (Şehirali, 1997; Castroluna ve ark., 2014).

Laboratuar Denemesinde Yapılan Gözlem ve Ölçümler: Denemede her gün aynı saatte gözlemler yapılmış ve Soltani ve ark. (2012)'nın bildirdiği gibi kökçük uzunluğu 2 mm'yi geçen tohumlar çimlenmiş olarak kabul edilmiştir. 10. günün sonunda toplam çimlenen tohumlar sayılarak çimlenme yüzdesi (\%) belirlenmiş̧ir (Scott ve ark., 1984). Ayrıca, çimlenmenin 10. gününde her bir petri kabından 10 sürgün örnek olarak alınmış ve bu örneklerde sapçık ve kökçük uzunlukları ve yaş ağırlıkları ölçülmüştür. Daha sonra, sapçık ve kökçükler $70{ }^{\circ} \mathrm{C}$ sıcaklıkta 6 saat kurutulduktan sonra tartılarak kuru ağırlıkları belirlenmiştir (Abdul-Baki ve Anderson, 1970).

Sera Denemesi: Sera koşullarındaki saksı denemesi, kaplama uygulamaları ana parselleri, kuraklık stresleri alt parselleri oluşturacak şekilde iki faktörlü ve üç tekerrürlü bölünmüş parseller deneme deseninde kurulmuştur. Sera denemesinde yıkanarak steril edilmiş $1500 \mathrm{ml}$ hacimli saksılar kullanılmıștır. Saksılar \%50 toprak $+\% 50$ kum olacak şekilde hazırlanan karışımlar ile doldurulmuştur. Toplam 36 (3x4x3) saksı kuraklık denemesi için hazırlanmıştır. Denemede kullanılan toprak+kum karışımının kimyasal ve fiziksel özellikleri Tablo 1 de, sulama suyunun kimyasal özellikleri ise Tablo 2 de verilmiştir.

Tablo 1. Saksılarda kullanılan toprak+kum karışımının kimyasal ve fiziksel özellikleri

Table 1. Chemical and physical properties of soil + sand mixture used in pots

\begin{tabular}{lll}
\hline Özellikler & Tespit edilen miktar & Değerlendirme \\
\hline $\mathrm{pH}$ & 7.7 & Hafif alkali \\
Kireç, \% & 27.5 & Fazla kireçli \\
Organik madde, \% & 0.64 & Çok az \\
Toplam Azot, \% & 0.080 & $\mathrm{Az}$ \\
Fosfor, $\mathrm{kg} \mathrm{P}_{2} \mathrm{O}_{5} \mathrm{da}^{-1}$ & 2.25 & $\mathrm{Az}$ \\
Potasyum, $\mathrm{kg} \mathrm{K}_{2} \mathrm{O} \mathrm{da}^{-1}$ & 20.9 & $\mathrm{Az}$ \\
Kalsiyum, $\mathrm{kg} \mathrm{CaO} \mathrm{da}^{-1}$ & 1428.4 & Fazla \\
Magnezyum, $\mathrm{kg} \mathrm{MgO} \mathrm{da}^{-1}$ & 84.2 & Yeterli \\
Demir, ppm & 2.21 & $\mathrm{Az}$ \\
Mangan, ppm & 4.01 & Yeterli \\
Çinko, ppm & 0.38 & Az \\
Bakır, ppm & 0.73 & Yeterli \\
\hline
\end{tabular}


Tablo 2. Sulama suyunun kimyasal özellikleri

Table 2. Chemical properties of irrigation water

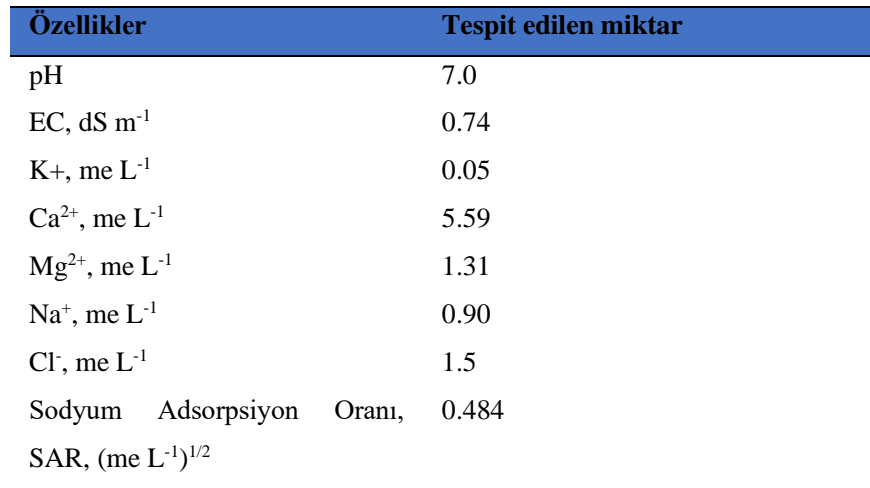

Denemenin yürütüldüğü günler için kaydedilen sıcak ve nem değerleri Tablo 3 de sunulmuştur.

ablo 3. Denemenin yürütüldüğg̈ günlere ait sıcaklık ve nem değerleri

Table 3. Temperature and humidity values of days of the experiment

\begin{tabular}{|c|c|c|c|c|}
\hline \multirow[t]{2}{*}{ Gün } & \multicolumn{2}{|c|}{ Sicaklık, ${ }^{\circ} \mathrm{C}$} & \multicolumn{2}{|c|}{ Nem, \% } \\
\hline & Minimum & Maximum & Minimum & Maximum \\
\hline 28.12.2017 & 9.1 & 32.5 & 13 & 75 \\
\hline 29.12.2017 & 9.0 & 34.5 & 12 & 78 \\
\hline 30.12 .2017 & 8.5 & 35.0 & 11 & 80 \\
\hline 31.12 .2017 & 8.7 & 33.0 & 12 & 77 \\
\hline 01.01 .2018 & 7.2 & 34.0 & 11 & 78 \\
\hline 02.01 .2018 & 7.0 & 33.2 & 12 & 65 \\
\hline 03.01 .2018 & 7.1 & 33.4 & 12 & 77 \\
\hline 04.01 .2018 & 11.1 & 21.1 & 56 & 64 \\
\hline 05.01 .2018 & 9.6 & 28.5 & 23 & 73 \\
\hline 06.01 .2018 & 7.5 & 32.0 & 18 & 70 \\
\hline 07.01.2018 & 6.8 & 33.0 & 15 & 69 \\
\hline 08.01.2018 & 6.5 & 33.3 & 12 & 68 \\
\hline 09.01 .2018 & 7.4 & 30.9 & 20 & 68 \\
\hline 10.01 .2018 & 8.3 & 30.6 & 22 & 69 \\
\hline 11.01.2018 & 13.3 & 26.7 & 31 & 69 \\
\hline 12.01 .2018 & 11.2 & 26.1 & 31 & 79 \\
\hline 13.01 .2018 & 10.5 & 27.5 & 18 & 78 \\
\hline 14.01 .2018 & 9.8 & 28.9 & 15 & 77 \\
\hline 15.01 .2018 & 7.3 & 32.4 & 14 & 79 \\
\hline 16.01 .2018 & 8.9 & 33.9 & 12 & 63 \\
\hline 17.01.2018 & 7.9 & 31.8 & 20 & 69 \\
\hline 18.01 .2018 & 11.3 & 31.6 & 18 & 70 \\
\hline 19.01.2018 & 7.8 & 29.2 & 18 & 58 \\
\hline 20.01 .2018 & 8.2 & 28.4 & 20 & 62 \\
\hline 21.01 .2018 & 11.3 & 18.5 & 52 & 69 \\
\hline 22.01 .2018 & 12.5 & 15.7 & 61 & 71 \\
\hline 23.01 .2018 & 11.5 & 22.5 & 35 & 70 \\
\hline 24.01 .2018 & 10.8 & 33.9 & 12 & 37 \\
\hline 25.01 .2018 & 8.4 & 31.3 & 14 & 33 \\
\hline 26.01 .2018 & 8.3 & 17.3 & 25 & 32 \\
\hline
\end{tabular}


Kaplanmış yonca tohumlarının çimlenme ve fide çıkış aşamasında kuraklığa toleranslarını ölçmek amacıyla önceden hazırlanmış olan her saksıya 20 adet yonca tohumu gelecek şekilde ekimler yapılmıştır. Daha sonra bütün saksılar tarla kapasitesinin \% 75 'ine kadar kuyu suyu ile sulanmıştır. Kuraklık stresi yaratmak için [T0 (0), T1 (\%25), T2 (\%50), T3 (\%75)] için 4 doz sulama rejimi belirlenmiştir. Kontrol saksılarına bu aşamadan sonra hiç su verilmemiştir. Diğer saksılara ise yapılan tartımlar sonucunda kaybettikleri su belirlenerek ve seçilen sulama rejimlerine uygun miktarlarda su verilmiştir.

Sera Denemesinde Yapılan Gözlem ve Ölçümler: Denemede her gün aynı saatte gözlemler yapılmış ve Aşçı ve Üney (2016)'in bildirdiği gibi sapçıkları toprak üzerinde görülen tohumlar çıkış sağlamış olarak kabul edilmiştir. Saksı denemeleri toplam 28 gün sürmüştür. Deneme sonunda her bir saksıdan 5 fide örnek olarak alınmış ve bu örneklerde sapçık ve kökçük uzunlukları ve yaş ağırlıkları ölçülmüştür. Ayrıca, sapçık ve kökçükler $70^{\circ} \mathrm{C}$ sıcaklıkta 6 saat kurutulduktan sonra tartılarak kuru ağırlıkları belirlenmiştir (Abdul-Baki ve Anderson, 1970).

Deneme sonucu elde edilen veriler; deneme desenlerine uygun olarak varyans analizine tabi tutulmuş ve ortalamalar \%5 önem seviyesinde Duncan testine göre karşılaştırılmıştır. Bu amaçla SPSS paket programı kullanılmıştır.

\section{Laboratuvar Denemesi}

\section{Bulgular}

Kaplanmış yonca tohumları PEG-6000 ile oluşturulan kuraklık stresi koşullarında çimlenmeye bırakılmıştır. 10 günlük çimlenme süresi sonunda açılan petrilerde yapılan gözlemlerde 0 (kontrol), -2, -4, ve -6 bar su tutma basınçları ile oluşturulan kuraklık stresi koşullarında çimlenme gerçekleşirken, -8 ve -9.8 bar basınç şartlarında çimlenme olayı gerçekleşmemiştir. (Sonuçlar incelendiğinde, kaplama uygulamasının incelenen özellikler açısından sapçık kuru ağırlığı $(\mathrm{P}<0.01)$ dışındaki diğer özelliklerde istatistiksel anlamda önemli bir fark yaratmadığı görülmektedir (Tablo 4). Bununla beraber, kuraklık uygulamaları çimlenme oranı, kökçük uzunluğu, sapçık uzunluğu, sapçık yaş ağırlığı ve sapçık kuru ağırlığı özelliklerinde $(P<0.01)$ önemli farklılık yaratmıştır. Kökçük yaş ve kuru ağırlığı bakımından ise istatistiksel olarak anlamlı bir fark oluşturmamıştır.

Kaplama uygulamalarının kuraklık stresi altında çimlendirilen yonca tohumlarının çimlenme özelliklerine etkilerini gruplandırmak amacıyla yapılan Duncan testi sonuçları Tablo 4 de verilmiştir. Tablo 4 de görüldüğü gibi, kaplama uygulamalarının kuraklık stresi altında çimlenen yonca tohumlarına etkisi ile çimlenme oranı, kökçük uzunluğu, kökçük yaş ağırlığı, sapçık yaş ağırlığı, kökçük kuru ağırlığı özelliklerine ait ortalama değerler aynı grup içerisinde yer almıştır. Fakat, sapçık uzunluğu ve sapçık kuru ağırlığı ait ortalama değerlerde farklı gruplar meydana gelmiştir.

Tablo 4. Kaplama Uygulamalarında Elde Edilen Ortalama Değerler ve Duncan Grupları (Laboratuvar Denemesi) Table 4. Average values obtained in coating applications nad duncan groups (laboratory trial)

\begin{tabular}{|c|c|c|c|c|c|c|c|}
\hline $\begin{array}{l}\text { Kaplama } \\
\text { uygulamaları }\end{array}$ & $\begin{array}{l}\text { Çimlenme } \\
\text { oranı }(\%)\end{array}$ & $\begin{array}{l}\text { Kökçük } \\
\text { uzunluğu } \\
(\mathrm{cm})\end{array}$ & $\begin{array}{l}\text { Sapçık } \\
\text { uzunluğu } \\
(\mathrm{cm})\end{array}$ & $\begin{array}{l}\text { Kökçük yaş } \\
\text { ağırlığı } \\
\text { (mg bitki-1) }\end{array}$ & $\begin{array}{l}\text { Sapçık yaş } \\
\text { ağırlığı } \\
\left(\text { mg bitki }{ }^{-1}\right)\end{array}$ & $\begin{array}{l}\text { Kökçük } \\
\text { kuru ağırlığı } \\
(\text { mg bitki-1) }\end{array}$ & $\begin{array}{l}\text { Sapçık kuru } \\
\text { ağırlığı } \\
(\mathrm{mg} \text { bitki-1) }\end{array}$ \\
\hline 0 (Kontrol) & $58.00 \mathrm{a}^{1}$ & $1.58 \mathrm{a}$ & $1.52 \mathrm{~b}$ & $4.33 \mathrm{a}$ & $24.45 \mathrm{a}$ & $0.87 \mathrm{a}$ & $3.12 \mathrm{~b}$ \\
\hline Kaplama 1 & $60.50 \mathrm{a}$ & $1.61 \mathrm{a}$ & $1.79 \mathrm{a}$ & $2.79 \mathrm{a}$ & $16.29 \mathrm{a}$ & $0.62 \mathrm{a}$ & $4.04 \mathrm{a}$ \\
\hline Kaplama 2 & $60.08 \mathrm{a}$ & $1.58 \mathrm{a}$ & $1.46 \mathrm{~b}$ & $5.58 \mathrm{a}$ & $18.16 \mathrm{a}$ & $0.58 \mathrm{a}$ & $3.79 \mathrm{a}$ \\
\hline Önemlilik & öd & öd & öd & öd & öd & öd & ** \\
\hline
\end{tabular}

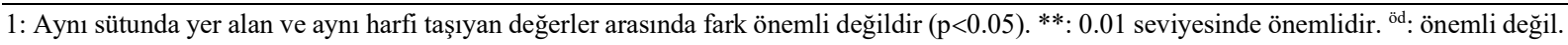

PEG-6000 ile oluşturulan, farklı seviyelerdeki kuraklık stresi koşullarında çimlendirilen kaplanmış yonca tohumlarının çimlenme oranı ve fide özelliklerine ait ortalama değerlere uygulanan Duncan testi sonuçları Tablo 5 de verilmiştir. 
JOTAF/ Journal of Tekirdag Agricultural Faculty, 2020, 17(2)

Tablo 5. Farkı Kuraklık Stresi Koşullarında Elde Edilen Ortalama Değerler ve Duncan Grupları (Laboratuvar Denemesi)

Table 5. Average values obtained under different drought stress conditions and duncan groups (laboratory trial)

\begin{tabular}{|c|c|c|c|c|c|c|c|}
\hline $\begin{array}{l}\text { Kuraklık dozları } \\
\text { (bar) }\end{array}$ & $\begin{array}{l}\text { Çimlenme } \\
\text { oranı (\%) }\end{array}$ & $\begin{array}{l}\text { Kökçük } \\
\text { uzunluğu } \\
(\mathrm{cm})\end{array}$ & $\begin{array}{l}\text { Sapçık } \\
\text { uzunluğu } \\
\text { (cm) }\end{array}$ & $\begin{array}{l}\text { Kökçük yaş } \\
\text { ağırlığı } \\
(\text { mg bitki-1 })\end{array}$ & $\begin{array}{l}\text { Sapçık yaş } \\
\text { ağırlığı } \\
\left(\mathbf{m g ~ b i t k i}{ }^{-1}\right)\end{array}$ & $\begin{array}{l}\text { Kökçük } \\
\text { kuru } \\
\text { ağırlığı } \\
\text { (mg bitki-1) }\end{array}$ & $\begin{array}{l}\text { Sapçık kuru } \\
\text { ağırlığı } \\
\left(\mathbf{m g} \text { bitki }^{-1}\right)\end{array}$ \\
\hline T0 & $87.83 b^{1}$ & $1.86 \mathrm{c}$ & $3.13 \mathrm{a}$ & $5.25 \mathrm{a}$ & $44.00 \mathrm{a}$ & $1.06 \mathrm{a}$ & $3.83 \mathrm{c}$ \\
\hline $\mathrm{T} 1$ & $85.16 \mathrm{c}$ & $2.25 \mathrm{~b}$ & $2.80 \mathrm{~b}$ & $8.58 \mathrm{a}$ & $28.66 \mathrm{~b}$ & $1.54 \mathrm{a}$ & $4.91 \mathrm{~b}$ \\
\hline $\mathrm{T} 2$ & $90.83 \mathrm{ab}$ & $2.61 \mathrm{a}$ & $2.08 \mathrm{c}$ & $8.75 \mathrm{a}$ & $22.00 \mathrm{~b}$ & $1.58 \mathrm{a}$ & $6.50 \mathrm{a}$ \\
\hline $\mathrm{T} 3$ & $93.33 \mathrm{a}$ & $2.84 \mathrm{a}$ & $1.52 \mathrm{~d}$ & $7.00 \mathrm{a}$ & $23.16 \mathrm{~b}$ & $1.41 \mathrm{a}$ & $6.66 \mathrm{a}$ \\
\hline Önemlilik(K) & $* *$ & ** & ** & $* *$ & $* *$ & $* *$ & ** \\
\hline Önemlilik $(K * K p)$ & öd & öd & öd & ** & öd & öd & öd \\
\hline
\end{tabular}

${ }^{1}$ : Aynı sütunda yer alan ve aynı harfi taşıyan değerler arasında fark önemli değildir (p<0.05). ${ }^{* * *} 0.01$ seviyesinde önemlidir. ${ }^{o ̈}:$ önemli değil. K: Kuraklık uygulaması, Kp: Kaplama uygulaması.

Tablo 5 incelendiğinde, çimlenme oranlarının \%85.16 (-2 bar) ile \%93.33 (-6 bar) arasında değiştiği ve artan kuraklık stresi ile beraber çimlenme oranlarında da bir artı̧̧ olduğu görülmektedir. Yonca fidelerinin kökçük uzunlukları kontrol uygulamasında $1.86 \mathrm{~cm}$ olarak tespit edilirken, -2 bar kuraklık stresinde $2.25 \mathrm{~cm}$, -4 bar kuraklık stresinde $2.61 \mathrm{~cm}$ ve -6 bar kuraklık stresinde de $2.84 \mathrm{~cm}$ olarak tespit edilmiştir. Kuraklık stresinin yükselmesiyle paralel olarak kökçük uzunlukları da artmıştır. Sapçık uzunlukları ise $1.52 \mathrm{~cm}$ (-6 bar) ile $3.13 \mathrm{~cm}$ (kontrol) arasında değişmiştir. Artan kuraklık stresi sapçık uzunluklarında önemli düzeyde kısalmaya sebep olmuştur.

Kuraklık stresi altında çimlendirilen kaplanmış yonca tohumlarının kökçük ağırlıkları incelendiğinde, kökçük yaş ağırlığına ait değerler $5.25 \mathrm{mg}$ (kontrol) ile $8.75 \mathrm{mg} \mathrm{(-4} \mathrm{bar)} \mathrm{arasında} \mathrm{değişmiştir.} \mathrm{Kökçük} \mathrm{yaş}$ ağırlıkları değerleri 1 grup altında toplanmış ve kuraklık stresi ile beraber bir artış yaşanmış fakat -6 bar kuraklık stresinden sonra tekrar azalmaya başlamıştır. Kökçük kuru ağırlıkları ise kontrol uygulamasında 1.06 $\mathrm{mg},-2$ bar da $1.54 \mathrm{mg},-4$ bar da $1.58 \mathrm{mg}$ ve -6 bar kuraklık stresinde $1.41 \mathrm{mg}$ olarak belirlenmiştir. Elde edilen ortalama değerler tek grup altında toplanmıştır.

Diğer yandan, sapçık yaş ağırlı̆ğ değerleri kontrol uygulamasında $44.00 \mathrm{mg}$ iken, -2 bar da $28.66 \mathrm{mg}$, -4 bar da 22.00 mg ve -6 bar kuraklık stresi koşullarında 23.16 mg olarak tespit edilmiştir. Elde edilen veriler genel olarak değerlendirildiğinde kuraklık stresinin çimlenen yonca fidelerinde sapçık yaş ağırlıklarını azalttığı görülmektedir. Sapçık kuru ağırlığına ait değerler ise $3.83 \mathrm{mg}$ (kontrol) ile $6.66 \mathrm{mg}$ (-6 bar) arasında değ işmiştir. Kuraklık stresinin yoğunluğu arttıkça fidelerin sapçık kuru ağırlığı değerleri artmış ve ortalama değerler ile 4 farklı duncan grubu oluşmuştur.

\section{Sera Denemesi}

Kaplanmış yonca tohumları sera koşullarındaki hazırlanmış olan saksılara ekilmiş ve farklı düzeylerdeki kuraklık stresi koşullarında çimlenmeye bırakılmıştır. Ekimden sonra her gün aynı saatlerde yapılan çimlenme ve fide çıkış gözlemleri ve daha sonrasındaki fideler üzerinde ölçümler yapılmıştır. T0 uygulamasında ekimle birlikte sulama yapılmış olup, daha sonra hiç su verilmemiştir. T0 uygulamasında çimlenme görülmüş ve bu veriler kayıt edilmiştir. Ancak, kuraklık stresinden dolayı fideler bir süre sonra ölmüşlerdir. Sonuçlar, kaplama uygulamaları ve kaplama*kuraklık interaksiyonu açısından önemli bir istatistiki fark oluşmadığını, kuraklık uygulamaları arasında incelenen bütün özellikler açısından 0.05 seviyesinde önemli farklılıklar olduğunu göstermektedir.

Kaplama uygulamalarının, sera koşullarında tutulan saksılarda kuraklık stresi altında çimlendirilen yonca tohumlarının, çimlenme özelliklerine etkilerini gruplandırmak amacıyla yapılan Duncan testi sonuçları Tablo 6 da verilmiş̧ir. Kaplama uygulamaları, ortalama çimlenme oranlarını \%56.66'dan \%64.16'e (Kaplama 1) ve $\% 60.00$ (Kaplama 2)'a yükseltmiştir. Fidelerin kökçük uzunlukları $8.63 \mathrm{~cm}$ (kontrol), $8.42 \mathrm{~cm}$ (Kaplama 1) ve $8.52 \mathrm{~cm}$ (Kaplama 2) belirlenirken; sapçık uzunlukları ise, sırasıyla, 2.34, 2.24 ve $2.47 \mathrm{~cm}$ olarak tespit edilmiştir. Benzer şekilde, kökçük yaş ve kuru ağırlıkları, sırasıyla, 13.12, 12.74 ve $12.93 \mathrm{mg} /$ bitki ile 5.90 , 5.68 ve $6.37 \mathrm{mg} /$ bitki olarak tespit edilmiştir. Sapçık yaş ve kuru ağırlıkları ise 17.33, 15.76 ve $18.30 \mathrm{mg} / \mathrm{bitki}$ ile $8.01,7.30$ ve $8.63 \mathrm{mg} / \mathrm{bitki}$ olarak belirlenmiştir. 
Kaplanmış Yonca (Medicago sativa L.) Tohumlarının Kuraklık Stresi Koşullarında Çimlenme Özelliklerinin Belirlenmesi

Tablo 6. Kaplama Uygulamalarında Elde Edilen Ortalama Değerler ve Duncan Grupları (Sera Denemesi)

Table 6. Average values obtained in coating applications and duncan groups (greenhouse trial)

\begin{tabular}{|c|c|c|c|c|c|c|c|}
\hline $\begin{array}{l}\text { Kaplama } \\
\text { Uygulamaları }\end{array}$ & $\begin{array}{l}\text { Çimlenme } \\
\text { oranı }(\%)\end{array}$ & $\begin{array}{l}\text { Kökçük } \\
\text { uzunluğu } \\
\text { (cm) }\end{array}$ & $\begin{array}{l}\text { Sapçık } \\
\text { uzunluğu } \\
\text { (cm) }\end{array}$ & $\begin{array}{l}\text { Kökçük yaş } \\
\text { ağırlığı } \\
\left(\text { mg bitki }{ }^{-1}\right)\end{array}$ & $\begin{array}{l}\text { Sapçık yaş } \\
\text { ağırlığı } \\
\left(\mathbf{m g} \text { bitki }{ }^{-1}\right)\end{array}$ & $\begin{array}{l}\text { Kökçük } \\
\text { kuru ağırlığı } \\
\left(\text { mg bitki }{ }^{-1}\right)\end{array}$ & $\begin{array}{l}\text { Sapçık kuru } \\
\text { ağırlığı } \\
\text { (mg bitki-1) }^{-1}\end{array}$ \\
\hline 0 (Kontrol) & $56.66 \mathrm{a}^{1}$ & $8.63 \mathrm{a}$ & $2.34 \mathrm{a}$ & $13.12 \mathrm{a}$ & $17.33 \mathrm{a}$ & $5.90 \mathrm{a}$ & $8.01 \mathrm{a}$ \\
\hline Kaplama 1 & $64.16 \mathrm{a}$ & $8.42 \mathrm{a}$ & $2.24 \mathrm{a}$ & $12.74 \mathrm{a}$ & $15.76 \mathrm{a}$ & $5.68 \mathrm{a}$ & $7.30 \mathrm{a}$ \\
\hline $\begin{array}{l}\text { Kaplama } 2 \\
\text { Önemlilik }\end{array}$ & $\begin{array}{l}60.00 \mathrm{a} \\
\text { öd }\end{array}$ & $\begin{array}{l}8.52 \mathrm{a} \\
\text { öd }\end{array}$ & $\begin{array}{l}2.47 \mathrm{a} \\
\text { od }\end{array}$ & $\begin{array}{l}12.93 \mathrm{a} \\
\text { öd }\end{array}$ & $\begin{array}{l}18.30 \mathrm{a} \\
\text { öd }\end{array}$ & $\begin{array}{l}6.37 \mathrm{a} \\
\text { öd }\end{array}$ & $\begin{array}{l}8.63 \mathrm{a} \\
\text { odd }\end{array}$ \\
\hline
\end{tabular}

1: Aynı sütunda yer alan ve aynı harfi taşıyan değerler arasında fark önemli değildir $(\mathrm{p}<0.05) .{ }^{\text {od: }}$ önemli değil.

Kuraklık stresi koşullarında elde edilen ortalama değerlerin bulunduğu Tablo 7 incelendiğinde, çimlenme oranları bakımından 3 farklı grubun oluştuğu ve oranların \%40.00 (T0) ile \%72.77 (T3) arasında değiştiği ve azalan kuraklık ile beraber çimlenme oranlarında bir artış olduğu görülmektedir. Bu çimlenme oranları petri kaplarında yapılan denemeden elde edilen oranlardan daha düşük olarak görülmektedir. Buradaki farklılık, petri kaplarında 2 mm kökçük çıkartan tohumların görülmesiyle elde edilen değerin çimlenme oranı olarak hesaplanmasından kaynaklanmaktadır. Oysa ki, saksı denemelerinde toprağa ekim yapılmış olup, toprak yüzeyinde çıkış yapan bitkilerin sayılmasıyla elde edilen değerin hesaplanmasıyla çimlenme oranı bulunmuştur. Aslında bu değer çimlenme ve fide çıkış değeri olarak ifade edilebilir.

Yonca fidelerinin kökçük uzunlukları kontrol uygulamasında (T3) $13.69 \mathrm{~cm}$ olarak tespit edilirken, T2'de $11.35 \mathrm{~cm}$, T1'de $9.07 \mathrm{~cm}$ olarak ölçülmüştür. Sapçık uzunlukları ise 3.42 (T3), 3.22 (T2) ve $2.76 \mathrm{~cm}$ (T1) olarak belirlenmiştir. Kuraklık stresinin yükselmesiyle paralel olarak kökçük uzunlukları ve sapçık uzunlukları azalmıştır.

Kuraklık stresine maruz bırakılan kaplanmış yonca tohumlarının kökçük yaş ve kuru ağırlıkları, sırasıyla, 22.37 (T3), 18.73 (T2) ve 10.63 (T1) mg/bitki ile 10.40, 8.76 ve 4.78 olarak belirlenmiştir. Sapçık yaş ve kuru ağırlıkları ise, sırasıyla, 28.49, 24.94 ve 15.10 ile 13.22, 11.97 ve $6.74 \mathrm{mg} / \mathrm{bitki}$ olarak tespit edilmiştir. Kökçük ve sapçık yaş ve kuru ağırlıkları değerleri, yonca tohumunun çimlenme aşamasında kuraklık stresinden etkilendiğini ve fide özelliklerinde gerilemeye sebep olduğunu göstermektedir.

Tablo 7. Farkı Kuraklık Stresi Koşullarında Elde Edilen Ortalama Değerler ve Duncan Grupları (Sera Denemesi)

Table 7. Average values obtained under different drought stress conditions and duncan groups (greenhouse trial)

\begin{tabular}{|c|c|c|c|c|c|c|c|}
\hline $\begin{array}{l}\text { Kuraklık } \\
\text { dozları }\end{array}$ & $\begin{array}{l}\text { Çimlenme } \\
\text { oranı }(\%)\end{array}$ & $\begin{array}{l}\text { Kökçük } \\
\text { uzunluğu } \\
\text { (cm) }\end{array}$ & $\begin{array}{l}\text { Sapçık } \\
\text { uzunluğu } \\
(\mathrm{cm})\end{array}$ & $\begin{array}{l}\text { Kökçük yaş } \\
\text { ağırlığı } \\
\left(\text { mg bitki }{ }^{-1}\right)\end{array}$ & $\begin{array}{l}\text { Sapçık yaş } \\
\text { ağırlığı } \\
\left(\mathbf{m g} \text { bitki-1 }^{-1}\right.\end{array}$ & $\begin{array}{l}\text { Kökçük } \\
\text { kuru ağırlığı } \\
\left(\text { mg bitki }{ }^{-1}\right)\end{array}$ & $\begin{array}{l}\text { Sapçık kuru } \\
\text { ağırlığı } \\
(\text { mg bitki-1) }\end{array}$ \\
\hline T0 & $40.00 c^{1}$ & $0.00 \mathrm{~d}$ & $0.00 \mathrm{c}$ & $0.00 \mathrm{c}$ & $0.00 \mathrm{c}$ & $0.00 \mathrm{c}$ & $0.00 \mathrm{c}$ \\
\hline $\mathrm{T} 1$ & $56.66 \mathrm{~b}$ & $9.07 \mathrm{c}$ & $2.76 \mathrm{~b}$ & $10.63 \mathrm{~b}$ & $15.10 \mathrm{~b}$ & $4.78 \mathrm{~b}$ & $6.74 \mathrm{~b}$ \\
\hline $\mathrm{T} 2$ & $71.66 \mathrm{a}$ & $11.35 \mathrm{~b}$ & $3.22 \mathrm{a}$ & $18.73 \mathrm{a}$ & $24.94 \mathrm{a}$ & $8.76 \mathrm{a}$ & $11.97 \mathrm{a}$ \\
\hline $\mathrm{T} 3$ & $72.77 \mathrm{a}$ & $13.69 \mathrm{a}$ & $3.42 \mathrm{a}$ & $22.37 \mathrm{a}$ & $28.49 \mathrm{a}$ & $10.40 \mathrm{a}$ & $13.22 \mathrm{a}$ \\
\hline Önemlilik & & & & & & & \\
\hline
\end{tabular}

${ }^{1}$ : Aynı sütunda yer alan ve aynı harfi taşıyan değerler arasında fark önemli değildir $(\mathrm{p}<0.05) .{ }^{*}: 0.05$ seviyesinde önemlidir.

\section{Bulgular}

Nimet yonca çeşidinin yeni nesil biyolojik bir tohum kaplama preparatı ile kaplanmış tohumlarının kuraklık stresi koşullarında çimlenme oranları incelenmiştir. Deneme hem laboratuar koşullarında petrilerde çimlendirme şeklinde, hem de sera ortamında saksılarda tohum çıkış ve erken fide gelişmesi şeklinde gerçekleştirilmiştir. Birçok araştırmacının da (Çarpıcı ve Erdel, 2015; Sheaffer ve ark., 1988; Wu ve ark., 2011) bildirdiği sonuçlara paralel olarak iklimlendirme dolabında yapılan çimlendirme çalışmalarında, kuraklık stresinin çimlenme oranlarında, kuraklık yoğunluğu -6 bar seviyesine kadar arttıkça bir miktar artış (\%87.83'den \%93.33'e) olmakla beraber -8 ve -9.8 bar seviyelerinde çimlenme görülmemiştir. Kaplama uygulamaları da ortalama çimlenme oranlarında, az miktarda da (\%58.00'dan \%60.08'e) olsa iyileşme sağlamıştır. 
Kaplama uygulamaları tohumun orijinal haline göre daha büyük, yuvarlak, yumuşak, ağır ve uniform bir hale gelmesi amacıyla yapılmaktadır (Kaufman, 1991). Ayrıca, kaplama ile tohumun stres koşulları altında çimlenme performansını arttırmak mümkündür (Taylor ve ark., 1998). Sheaffer ve ark., (1988), kimyasal ve biyolojik preparatlarla kaplanan tohumların zor çevre şartlarında sağlıklı fide gelişimine ve iyi düzeyde bitki tesisi sağlamada çok yararlı olduğunu bildirmektedir. Esasen, kaplama yönteminin amaçlarından biri de stres koşulları altında tohumun çimlenme performansını arttırmak ve bu evrede hastalık ve zararlılarla mücadele materyallerinin taşınmasına olanak sağlamaktır (Taylor ve ark., 1998). Diğer bir ifade ile tohum uygulamaları, bitkilerin genetik ve fizyolojik potansiyellerinin açığa çıkması açısından önemli olan tohum çıkış ve fide gelişimini garanti altına almada önemlidir. $\mathrm{Bu}$ amaçla birçok biyolojik ürün tohumlara kaplama yoluyla taşınmakta ve başarılı olarak uygulanmaktadır (Junges ve ark., 2013).

Çarpıcı ve Erdel (2015), kuraklık stresi koşullarında çimlendirdikleri yonca tohumlarında çimlenme oranlarını çeşitlere göre değişmekle beraber \%6.50 ile \%99.00 arasında değişen miktarlarda tespit etmişlerdir. Araştırmacılar -10.27 bar kuraklık seviyesinde birçok çeşit de çimlenme elde edememişlerdir. Hamidi ve Safarnejad (2010), yonca çeşitlerinde PEG-6000 ile oluşturulan kuraklık stresinin etkilerini araştırdıkları makalelerinde, kuraklık stresinin çimlenme oranını azalttığını ve \%97 (0) ile \%21 (-9 bar) arasında değerler elde edildiğini bildirmektedirler.

Kökçük ve sapçık uzunluğu değerleri kuraklık stresinden etkilenmiş ve önemli düzeyde azalmalar meydana gelmiştir. Yonca çeşitlerinde kuraklık stresinin etkilerini araştıran Çarpıcı ve Erdel (2015), kökçük uzunluklarını $5.44 \mathrm{~cm}$ ile $2.55 \mathrm{~cm}$ arasında, sapçık uzunluklarını ise $4.38 \mathrm{~cm}$ ile $0.12 \mathrm{~cm}$ arasında değişen miktarlarda bulmuşlardır. Kuraklık stresi, kökçük ve sapçık uzunluğu değerlerinde önce bir miktar artış sağlamış daha sonra önemli miktarda azalmalara neden olmuştur. Hamidi ve Safarnejad (2010) benzer bulguları elde etmiş olup, kökçük uzunluklarını $7.10 \mathrm{~cm}$ ile $1.40 \mathrm{~cm}$ arasında, sapçık uzunluklarını da $4.60 \mathrm{~cm}$ ile $0.40 \mathrm{~cm}$ arasında değişen miktarlarda bulduklarını bildirmişlerdir.

Kökçük yaş ve kuru ağırlıkları ile sapçık yaş ve kuru ağırlıkları kuraklık stresinden önemli derecede etkilenmiştir. Fakat, tohum kaplama uygulamaları kuraklık stresi koşullarında kökçük yaş ve kuru ağırlıklarında artışlar meydana getirmiştir. Wang ve ark. (2009), kuraklık stresinin etkilerini araştırdıkları çalışmalarında fide yaş ağırlığını, \%0 PEG-6000 uygulamasında 25 mg, \%35 PEG-6000 uygulamasında 7.5 mg olarak belirlemişlerdir.

Kim ve ark. (2005), kaplanmış yonca tohumlarının meralarda yüzeysel ekimlerde başarı oranını arttırarak iyi bir çimlenme ve fide gelişimi sağladığını bildirmektedir. Diğer yandan, Samancıŏglu ve Yıldırım (2015), son zamanlarda stres koşulları altında yetiştirilen bitkilere tolerans kazandırmada bitki gelişimini teşvik eden bakteri kullanımının yaygınlaştığını ve bu sayede bitkilerde bitki gelişiminin ve verimin arttığını bildirmektedir.

Bilindiği üzere başarılı bir tarımsal üretimde, istenilen bitki sıklığının ve yüksek verimin elde edilmesi her şeyden önce ekilen tohumun hızlı, üniform ve eksiksiz bir şekilde çimlenip çıkış yapmasına bağlıdır. Ancak, bir taraftan çimlenmenin sıcaklık, nem, toprak tuzluluğu gibi çevresel faktörlerden etkilenmesi (Kantar ve Elkoca, 1998; Turk ve ark., 2004), diğer taraftan ekilen tohumluğun çoğu kere genetik yapı, tohum olgunluğu ve tohum büyüklüğü bakımından üniform olmaması (McDonald, 2000) eşzamanlı çimlenme ve çıkışa engel olmakta, çimlenme ve çıkış oranı azalmakta ve bunun sonucunda istenilen bitki sıklığı sağlanamamaktadır. Özellikle ilkbahar ekimlerinde hüküm süren düşük toprak sıcaklıkları çoğu kere hızlı çimlenme ve çıkış için uygun değildir. Bu şartlar altında çıkış yapan fideler yavaş büyümekte, tohum ve toprak kökenli patojenlere karşı daha fazla hassasiyet göstermektedirler (Matthews ve ark., 2012).

\section{Sonuç}

Kuraklık stresinin şiddetin artmasıyla beraber yonca tohumlarının çimlenme, çıkış ve erken fide gelişme özellikleri etkilenmiştir. Kaplama uygulamaları ise incelenen özellikler üzerinde olumlu etkiler yapmıştır. Yonca çimlenme ve erken fide gelişme döneminde çok zayıf gelişme gösteren bir bitkidir. Bu çalışma sonuçları, tohumları kaplanmak suretiyle çevresel etkilere karşı zayıf oldukları bu dönemlerinde desteklenmesinin mümkün olduğu anlaşılmıştır. Yonca yem bitkileri içeresinde en fazla ekim alanına sahip olan ve giderek yaygınlaşan bir bitki olarak önemlidir. Yem bitkileri tarımı içerisindeki öneminin yanında mera ıslah projelerinde tercih edilmektedir. Kaplanmış yonca tohumlarının mera ıslah çalışmalarında üstten tohumlama yönetimi ile kullanılma olanaklarını düşünüldüğünde, toprağa bırakılan tohumların özellikle 
Kaplanmış Yonca (Medicago sativa L.) Tohumlarının Kuraklık Stresi Koşullarında Çimlenme Özelliklerinin Belirlenmesi

kuraklık periyodlarında çimlenme ve erken fide gelişimi gösterebilmeleri son derece hayati öneme sahiptir. Bilindiği gibi yonca, kökleri çok derinlere inebilen ve toprağın derin katmanlarından faydalanabilen bir bitkidir. Dolayısıyla bitki çimlenme döneminde hayatta kalabilir ve kök gelişimini tamamlayabilirse uzun süre mera ortamında kalması mümkün olacaktır. Trichoderma harzianum, Bacillus subtilis ve Bacillus megaterium içeren Panoramix ile kaplanan yonca tohumlarının kuraklık toleransı arttığı için mera 1slahında da bu amaçla kullanılabileceği anlaşılmaktadır. Bu çalışma, benzer kaplama preparatları ile zenginleştirilerek yonca tohumlarının çimlenme kaliteleri arttırılabilir.

\section{Teşekkürler}

Bu çalışma Akdeniz Üniversitesi Bilimsel Araştırma Projeleri tarafından desteklenmiştir (FYL-20172373). 


\section{Kaynakça/References}

Abdul-baki AA, Anderson JD, 1970. Viability and leaching of sugars from germinating barley. Crop Science, 10: 31-34.

Açıkgöz E, 2001. Yem Bitkileri (3. Baskı) Uludağ Üniv. Güçlendirme Vakfı Yayın No: 182, Bursa.

Ahmadi S, Ahmad R, Ashraf MY, Ashraf M, Waraich EA, 2009. Sunflower (Helianthus annuus L.) Response to Drought Stress at Germination and Seedling Growth Stages. Pak. J. Bot., 41(2): 647-654.

Aşçı ÖÖ, Üney H, 2016. Farklı tuz yoğunluklarının macar fiğinde (Vicia pannonica Crantz) çimlenme ve bitki gelişimine etkisi. Akademik Ziraat Dergisi, 5(1): 29-34.

Avcıoğlu R, Geren H, Tamkoç A, Karadağ Y, 2009. Yonca (Medicago sp. L.). YEMBİTKİLERİ, Baklagil Yembitkileri, Cilt II, T.C. Tarım ve Köyişleri Bakanlığı, Tarımsal Üretim ve Geliştirme Genel Müdürlüğü, İzmir.

Blum A, 1986. "Breeding Crop Varieties for Stress Environments”, Critical Reviews in Plant Sciences, 2: $199-237$.

Castroluna A, Ruiz OM, Quiroga AM, Pedranzani HE, 2014. Effects of salinity and drought stres on germination, biomass and growth in three varieties of Medicago sativa L. Avances en Investigacion Agropecuaria, 18(1): 39-50.

Çarpıcı EB, Erdel B, 2015. Bazı yonca çeşitlerinde (Medicago sativa L.) kuraklık stresinin çimlenme özellikleri üzerine etkisi. Derim, 32(2): 201-210

Deaker R, Roughley RJ, Kennedy IR, 2004. Legume seed inoculation technology-a review. Soil Biology and Biochemistry, 36: 1275-1288.

Demiroğlu G, Geren H, Avcıoğlu R, 2008. Farklı Yonca (Medicago sativa L.) Genotiplerinin Ege Bölgesi Koşullarına Adaptasyonu. Ege Üniv. Ziraat Fak. Derg., 45 (1): 1-10.

Eskandari H, 2013. Effects of Priming Technique on Seed Germination Properties, Emergence and Field Perfromance of Crops: A review. Intl.J.Agron.Plant.Prod., 4(3): 454-458.

Hamidi H, Safarnejad A, 2010. Effect of Drought Stress on Alfalfa Cultivars (Medicago sativa L.) in Germination Stage. American-Eurasian J. Agric. and Environ. Sci., 8(6): 705-709.

Heydecker W, Gibbins, B, 1978. The `priming` of seeds. Acta Horticulturae, 83: 213-215.

Ingram J, Bartles D, 1996. The molecular basis of dehydration tolerance in plants. Ann. Rev. Plant Physiol. Plant Mol. Biol., 47: $377-403$.

Janmohammadi M, Moradi Dezfuli P, Sharifzadeh F, 2008. Seed Invigoration Techniquse to Improve Germination and Early Growth of Inbred Line of Maize under Salinity and Drought Stress. Plant physiology, 34(3-4): 215-226.

Junges E, Toebe M, Santos RF, Finger G, Muniz MFB, 2013. Effect of priming and seed-coating when associated with Bacillus subtilis in maize seeds. Revista Ciência Agronômica, 44(3):520-526.

Kalefetoğlu T, Ekmekçi Y, 2005. The Effects of Drought on Plants and Tolerance Mechanisms. G.U. Journal of Science, 18(4): 723-740.

Kantar F, Elkoca E, 1998. Kültür bitkilerinde tuza dayanıklılık. Atatürk Üniv. Ziraat Fak. Derg., 29 (1): 163-174.

Kaufman G, 1991. Seed Coating: A Tool for Stand Establisment; a Stimulus to Seed Quality. HortTechnology, http://horttech.ashspublications.org/content/1/1/98.full.pdf, Erişim tarihi: 20.05.2018.

Kim JD, Kwon CH, Kim SG, Kim JK, Hur SN, 2005. Development of Seed Pelleting Technique for Surface Sowing of Alfalfa. Journal of Animal Science and Technology, 47(3): 475-480.

Matthews S, Noli E, Demir I, Khajeh-Hosseini M, Wagner MH, 2012. Evaluation of seed quality: from physiology to international standardization. Seed Science Research (22): 69-73.

McDonald MB, 2000. Seed Priming. In: Black M, Bewley JD, (ed.) Seed Technology and Its Biological Basis. 287-325. Sheffield Academic Press, Sheffield, UK.

Michel BE, Kaufmann MR, 1973. The osmotic potential of polyethylene glycol 6000. Plant Physiology, 51: 914-16.

Mostafavi K, 2011. A Study Effects of Drought Stress on Germination and Early Seedling Growth of Flax (Linum usitatissimum L.) Cultivars. Advances in Environmental Biology, 5(10): 3307-3311.

Örs S, Ekinci M, 2015. Kuraklık Stresi ve Bitki Fizyolojisi. Derim, 32(2): 237-250.

Pecetti L, Romani M, Rosa LD, Piano E, 2008. Selection of grazing-tolerant lucerne cultivars. Grass and Forage Science, 63, 360-368.

Rashmi R, Sarkar M, Vikramaditya, 1997. Cultivation of Alfalfa (Medicago sativa L.) Ancient Science of Life, 17 (2): $117-119$

Samancıoğlu A, Yıldırım E, 2015. Bitki Gelişimini Teşvik Eden Bakteri Uygulamalarının Bitkilerde Kuraklığa Toleransı Arttırmadaki Etkileri. Mustafa Kemal Üniversitesi Ziraat Fakültesi Dergisi, 20(1): 72-79. 
Kaplanmış Yonca (Medicago sativa L.) Tohumlarının Kurakllk Stresi Koşullarında Çimlenme Özelliklerinin Belirlenmesi

Scott SJ, Jones RA, Williams WA, 1984. Review of data analysis methods for seed germination. Crop Science, 24: 1192-1199.

Sheaffer CC, Hall MH, Martin NP, Rabas DL, Ford JH, Warnes DD, 1988. Effects of Seed Coating on Forage Legume Establishment in Minnesota. Station Bulletin 584-1988 (Item Number AD-SB-3422) Minnesota Agricultural Experiment Station University of Minnesota. Ss, 16 .

Soltani A, Khodarahmpour Z, Jafari AA, Nakhjavan S, 2012. Selection of alfalfa (Medicago sativa L.) cultivars for salt stres tolerance using germination indices. African Journal of Biotechnology, 11(31): 7899-7905.

Şehirali, S. 1997. Tohumluk ve Teknolojisi. Trakya Üniversitesi Ziraat Fakültesi Tarla Bitkileri Bölümü, 422 s.

Taylor, A. G., Allen, P. S., Bennett, M. A., Bardford, K. J., Burris, J. S., Misra, M. K., 1998, Seed Enhancements, Seed Sc. Res. 8, USA:245256.

Turk, M.A., Rahman, A., Tawaha, M., Lee, K.D., 2004. Seed germination and seedling growth of three lentil cultivars under moisture stress. Asian Journal of Plant Sciences, 3 (3): 394-397.

Valdes VM, Bradford KJ, 1987. Effects of seed coating and osmotic priming on the germination of lettuce seeds. J. Amer. Soc. Hort. Sci. 112:153-156.

Vavrina CS, McGovern RJ, 1990. Seed treatments target soilborne diseases. Amer. Veg. Grower 38(13):63-64.

Wang Y, Li K, Li X, 2009. Auxin redistribution modulates plastic development of root system architecture under salt stress in arabidopsis thaliana. Journal of Plant Physiology 166:1637-1645.

Wu C, Wang Q, Xie B, Wang Z, Cui J, Hu T, 2011. Effects of Drought and salt Stress on Seed Germination of Three Leguminous Species. African Journal of Biotechnology, 10 (78), 17954-17961.

Yüksel O, Albayrak S, Türk M, Sevimay CS, 2016. Dry Matter Yields and Some Quality Features of Alfalfa (Medicago sativa L.) Cultivars under Two Different Locations of Turkey. Süleyman Demirel Univesity Journal of Natural and Applied Sciences, 20(2): 155-160. 